CZASOPISMO INŻYNIERII LA¿OWEJ, ŚRODOWISKA I ARCHITEKTURY JOURNAL OF CIVIL ENGINEERING, ENVIRONMENT AND ARCHITECTURE JCEEA, t. XXXIII, z. 63 (2/I/16), kwiecień-czerwiec 2016, s. 21-30

\author{
January BIEN' ${ }^{1}$ \\ Tomasz KAMIZELA ${ }^{2}$ \\ Anna GROBELAK ${ }^{3}$ \\ Anna GROSSER \\ Zbigniew DYK ${ }^{5}$ \\ Daniel SZTUCHLIK ${ }^{6}$ \\ Małgorzata KACPRZAK ${ }^{7}$
}

\title{
WŁAŚCIWOŚCI FIZYCZNO-CHEMICZNE BIOMASY OTRZYMANEJ W NOWEJ TECHNOLOGII PRZETWARZANIA OSADÓW ŚCIEKOWYCH ,BIONOR SLUDGE”
}

\begin{abstract}
Obecny stan prawny w pewien sposób generuje poszukiwania i rozwój nowoczesnych technologii pozwalających na rozwiązanie problemu zagospodarowania osadów ściekowych w Polsce nie tylko dla dużych obiektów, ale przede wszystkim dla instalacji małych i średnich, ponieważ to z nich głównie osady ściekowe obecnie trafiają na składowiska odpadów. Celem pracy jest ocena funkcjonowania prototypowej linii technologicznej do przetwarzania osadów ściekowych i ocena uzyskanej z tej technologii biomasy. Technologia Bionor Sludge stanowi rozwiązanie przeznaczone dla gminnych oczyszczalni o przepustowości do $1000 \mathrm{~m}^{3} * \mathrm{~d}^{-1}$. Powstające osady ściekowe odpowiednio przetworzone w instalacji mogą zostać zagospodarowane dwojako: jako kompost lub jako wsad do instalacji termicznej, gdzie mogą stanowić biomasę zgodnie $\mathrm{z}$ ustawą o OZE. W pracy przedstawiono materiały pozwalające na wstępną ocenę jakości uzyskiwanego produktu pod kątem potencjału nawozowego i energetycznego. Bionor Sludge to technologia, która polega na przekierowaniu, w możliwie największym stopniu, energii chemicznej zgromadzonej w ściekach komunalnych do osadów stanowiących rezerwuar substancji organicznej. Cały układ technologiczny oczyszczania ścieków i przeróbki osadów charakteryzuje się również wysoką efektywnością i elastycznością pracy przy modułowej zabudowie. Możliwe i w pełni zasadne jest zastosowanie wybranych elementów omawianej instalacji w ramach modernizacji istniejących obiektów. Technologia Bionor Sludge dzięki swej innowacyjności i założeniom o możliwie najlepszym wykorzystaniu zasobów nawozowych i energetycznych, umożliwia racjonalne funkcjonowanie oczyszczalni i tym samym znaczące odciążenie budżetu gmin i ostatecznie ich mieszkańców.
\end{abstract}

\footnotetext{
${ }^{1}$ January Bień, Politechnika Częstochowska, ul. J.H. Dąbrowskiego, 42-200 Częstochowa, telefon 34 3250917, jbien@is.pcz.czest.pl

2 Tomasz Kamizela, Politechnika Częstochowska, tkamizela@is.pcz.czest.pl

${ }^{3}$ Autor do korespondencji/corresponding author: Anna Grobelak, Politechnika Częstochowska, ul. J.H. Dąbrowskiego, 42-200 Częstochowa, telefon 34 3250917, agrobelak @is.pcz.czest.pl

4 Anna Grosser, Politechnika Częstochowska, agrosser@is.pcz.czest.pl

${ }^{5}$ Zbigniew Dyk, BIONOR Sp. z o.o., ul. Ściegiennego 26, 25-115 Kielce, tel. kom. 601977622 , zbigniew.dyk@bionor.pl

${ }^{6}$ Daniel Sztuchlik, BIONOR Sp. z o.o. Kielce, tel. kom. 601977 622, daniel.sztuchlik@bionor.pl

${ }^{7}$ Małgorzata Kacprzak, Politechnika Częstochowska, mkacprzak@is.pcz.czest.pl,
} 
Słowa kluczowe: gospodarka osadowa, oczyszczanie ścieków, kompost, biomasa, OZE

\section{Wprowadzenie}

W Polsce w 2013 roku wyprodukowano ponad 555 tys. Mg s.m. osadów ściekowych [1]. W kraju pracuje ponad 3,2 tys. oczyszczalni ścieków [1], z czego około połowa to obiekty o wydajności 2000 RLM oraz poniżej. Ilość produkowanych przez nie osadów ściekowych jest relatywnie niewielka, jednak każda z oczyszczalni boryka się z problemem ich zagospodarowania. Zgodnie z obowiązującym prawodawstwem (Rozporządzenie Ministra Środowiska $\mathrm{z}$ dnia 6 lutego 2015 r. w sprawie komunalnych osadów ściekowych) osady ściekowe mogą być zagospodarowane przyrodniczo [2]. Rozporządzenie to określa szczegółowe warunki stosowania komunalnych osadów ściekowych, w tym dawki osadów, które można stosować na gruntach oraz zakres, częstotliwość i metody referencyjne badań komunalnych osadów ściekowych i gruntów, na których osady mają być stosowane. Inną możliwością jest uzyskanie, po przeprowadzeniu procesów przetwórczych w tym np. przekompostowaniu, nawozu lub środka nawozowego zgodnie z Rozporządzeniem Ministra Rolnictwa i Rozwoju Wsi z dnia 18 czerwca 2008 roku w sprawie wykonania niektórych przepisów ustawy o nawozach i nawożeniu [3]. Obecnie, osady ściekowe są także poddawane przekształceniu termicznemu lub składowaniu. Zgodnie z Rozporządzeniem [4] od 1.01.2016 r. jest niedopuszczalne ich składowanie na składowiskach odpadów. Natomiast ustawa o OZE z dnia 20 lutego 2015 dopuszcza stosowanie osadów ściekowych jako biomasy do procesów termicznych [5].

Obecny stan prawny w pewien sposób generuje poszukiwania i rozwój nowoczesnych technologii pozwalających na rozwiązanie problemu zagospodarowania osadów ściekowych nie tylko dla dużych obiektów, ale przede wszystkim dla instalacji małych i średnich, ponieważ to $\mathrm{z}$ nich głównie osady ściekowe obecnie trafiają na składowiska odpadów. Technologia Bionor Sludge [6] stanowi rozwiązanie przeznaczone dla gminnych oczyszczalni o przepustowości do $1000 \mathrm{~m}^{3} * \mathrm{~d}^{-1}$. Powstające osady ściekowe odpowiednio przetworzone $\mathrm{w}$ instalacji mogą zostać zagospodarowane dwojako: jako kompost lub jako wsad do instalacji termicznej, gdzie mogą stanowić biomasę zgodnie z ustawą o OZE. W pracy przedstawiono materiały pozwalające na wstępną ocenę jakości uzyskiwanego produktu pod kątem potencjału nawozowego i energetycznego.

\section{Opis technologii Bionor Sludge}

Technologia Bionor Sludge jest testowana w gminnej oczyszczalni ścieków w Łubowie (woj. wielkopolskie) o przepustowości $250 \mathrm{~m}^{3 *} \mathrm{~d}^{-1}$. W skład układu technologicznego oczyszczalni ścieków w Łubowie wchodzi stopień mechanicznego oraz biologicznego oczyszczania. Wstępnie, na sicie kanałowym oddzielana jest duża frakcja ciał stałych, a ścieki kierowane są na filtr taśmowy. 
Zadaniem filtra taśmowego jest separacja pozostałych cząstek stałych, jak i osadów nadmiernych z biologicznego procesu oczyszczania ścieków. Filtr taśmowy posiada również system odwadniania osadów za pomocą prasy zintegrowanej z sitem szczelinowym. W całym procesie odwadniania nie ma potrzeby zastosowania kondycjonowania osadów przy pomocy polielektrolitów. Wyeliminowanie tego zabiegu znacząco obniża koszty eksploatacji takiej oczyszczalni. Stosowana technologia Bionor Sludge umożliwia redukcję obciążenia reaktorów biologicznych poprzez wysokowydajną filtrację na prasie filtracyjnej i usunięcie zawiesin ze ścieków. Pozostała substancja organiczna w formie związków rozpuszczonych i koloidów kierowana jest do reaktorów biologicznych SBR, które zasilane są łatwo biodegradowalnymi frakcjami ścieków. Efektem zastosowania technologii Bionor Sludge jest również zmniejszenie ilości osadów nadmiernych wymagających przetwarzania, w tym ich stabilizacji. Od strony eksploatacyjnej zminimalizowano również komplikacje ze stabilnością i efektywnością pracy reaktorów sekwencyjnych. Stężenia limitowanych zanieczyszczeń w ściekach oczyszczonych, w tym azotu i fosforu ogólnego, nie wykazują przekroczeń stężeń dopuszczalnych (Rys. 1).

Innowacyjnym w technologii Bionor Sludge jest rozwiązanie polegające na mieszaniu osadów nadmiernych $\mathrm{z}$ roztworem środka strukturotwórczego (Rys. 2). Uzyskana mieszanina kierowana jest następnie współ-strumieniowo ze ściekami do filtra taśmowego. Odwodnione osady nadmierne wraz z osadami surowymi stanowią wsad kompostowy (osady mieszane), transportowany do termo - kompostownika, który jest trójstrefowym termo-bioreaktorem. Poddanie osadów nadmiernych procesowi kompostowania zastępuje jego stabilizację w ciągu technologicznym oczyszczania ścieków (Rys. 2).

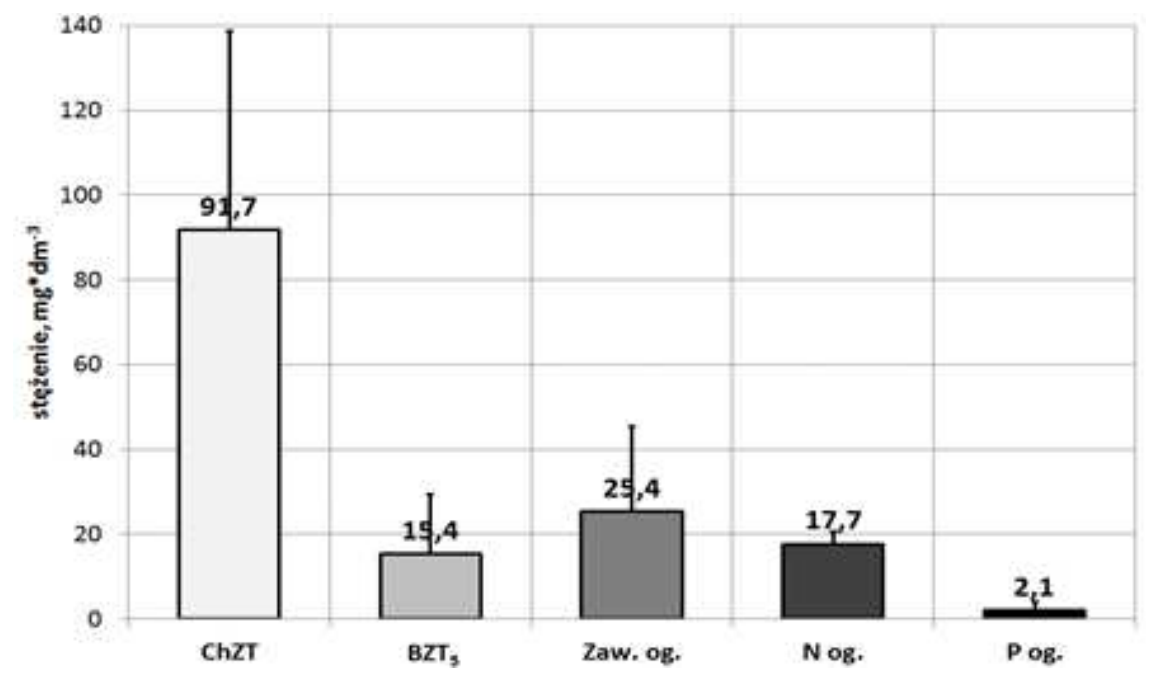

Rys. 1. Średnioroczne wartości wskaźników zanieczyszczeń w ściekach oczyszczonych w roku 2015, na podstawie [7]

Fig. 1. The average annual values of pollutants in the treated wastewater in 2015, based on [7] 


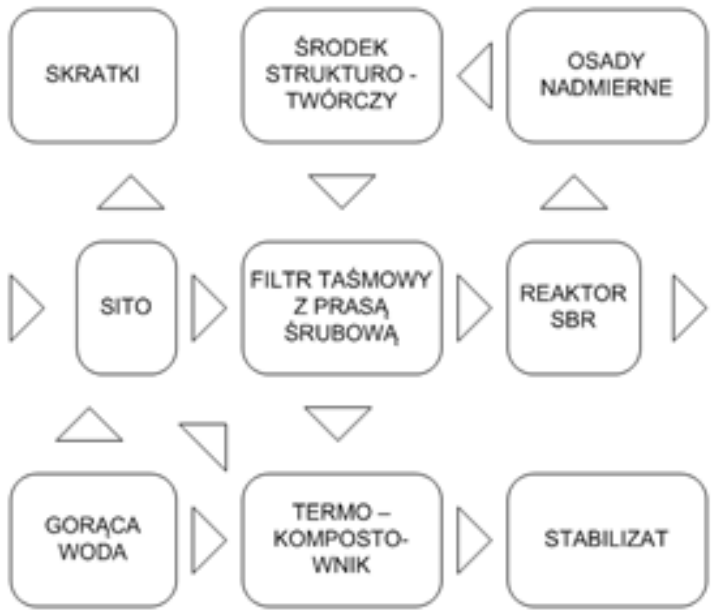

Rys. 2. Schemat technologiczny oczyszczalni w Łubowie k \Gniezna z wdrożoną technologią Bionor Sludge, na podstawie [6]

Fig. 2. Technological scheme of wastewater treatment plants in Lubowo near Gniezno with the implemented Bionor Sludge technology, based on [6]

Proces termo - kompostowania intensyfikowany jest poprzez zastosowanie układów: mieszania, podgrzewania oraz napowietrzania. Czas kompostowania (zatrzymania w termo - kompostowniku) wynosi zazwyczaj od 5 do 7 dni, przy zapewnieniu ciągłości procesu kompostowania. Temperatura minimalna rzędu $70^{\circ} \mathrm{C} \mathrm{w}$ kompostowniku powoduje również higienizację powstałej biomasy oraz zmniejsza jej uwodnienie z $65 \%$ do blisko $15 \%$, co jest ogromną zaletą całego procesu (Rys. 3).

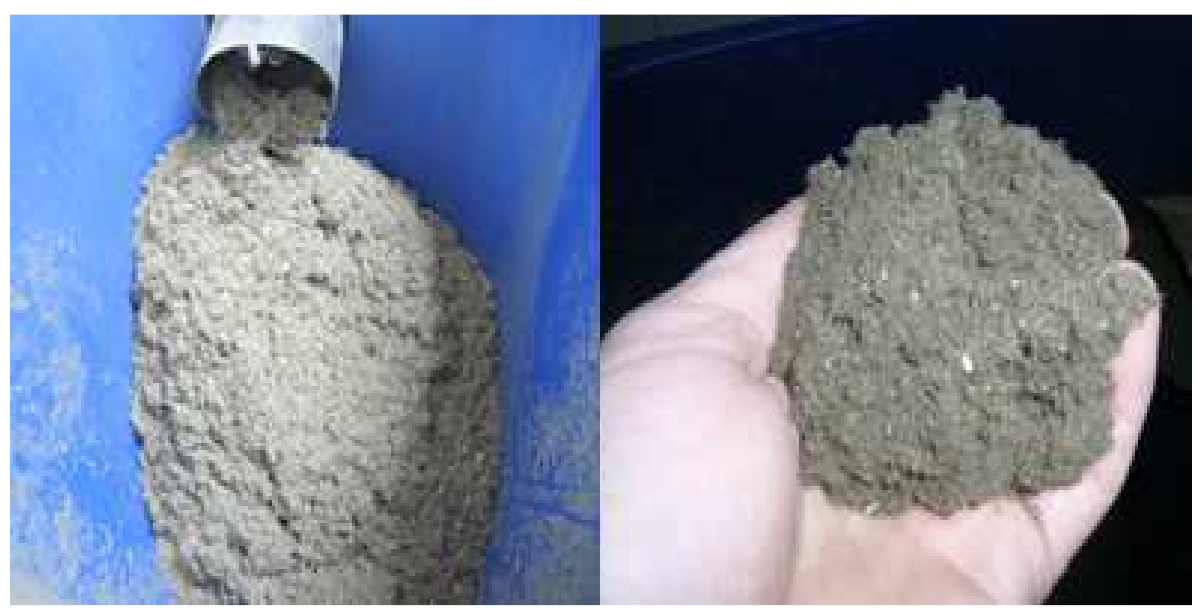

Rys. 3. Produkt termo - kompostowania w technologii Bionor Sludge

Fig. 3. Product of the thermo - composting technology Bionor Sludge 


\section{Metodyka badań}

W pracy przeprowadzono wyniki analiz ścieków oczyszczonych w oparciu o kwartalne sprawozdania badań z roku 2015. Badania zostały wykonane przez akredytowane laboratorium na zlecenie firmy Bionor [7]. Przedmiotowe oznaczenia i metody badawcze były następujące: ChZT, (PN-ISO 6060:2006), BZT5 (PN-EN 1899-1:2002), zawiesina ogólna (PN-EN 872:2007 + Ap1:2007), Azot ogólny (PB/PFO-13 wyd. 3 z dnia 01/07/2013), fosfor ogólny (PN-EN ISO 6878:2006 + Ap1 + Ap2/2010)

W pracy zawarto wyniki badań ilościowo - jakościowych odwodnionych osadów mieszanych (wstępny oraz wtórny) i uzyskanego produktu termo kompostowania oraz powstałych w czasie termicznej utylizacji popiołów. Oznaczenia wykonano na próbach pobieranych w odstępach miesięcznych w okresie czterech miesięcy. Analizy zostały wykonane w Instytucie Inżynierii Środowiska zgodnie z obowiązującymi normami:

- PN-EN 12879:2004 - Charakterystyka osadów ściekowych - Oznaczanie strat przy prażeniu suchej masy osadu,

-PN-EN 12880:2004 - Charakterystyka osadów ściekowych - Oznaczanie suchej pozostałości i zawartości wody,

- PN-Z-15011-3:2001 - Kompost z odpadów komunalnych -- Oznaczanie: pH, zawartości substancji organicznej, węgla organicznego, azotu, fosforu i potasu,

- PN-EN 11885:2009 - Oznaczanie wybranych pierwiastków metodą optycznej spektrometrii emisyjnej z plazmą wzbudzoną indukcyjnie (ICP-OES),

- PN-G-04571:1998 Oznaczanie zawartości węgla, wodoru i azotu automatycznymi analizatorami - Metoda makro,

-PN-G-04584:2001 - Paliwa stałe - Oznaczanie zawartości siarki całkowitej i popiołowej automatycznymi analizatorami,

-Zawartość tlenu i fosforu - wyliczone w oparciu o skład CHNS, oznaczony przy użyciu spektrometru XRF,

- PN-ISO 1928:2002 - Paliwa stałe - Oznaczanie ciepła spalania metodą spalania w bombie kalorymetrycznej i obliczanie wartości opałowej.

\section{Wyniki badań $i$ ich analiza}

Analiza produktu powstającego w kompostowniku polegała na oszacowaniu parametrów nawozowych oraz energetycznych. Przeprowadzona analiza składu elementarnego, głównie w zakresie niebezpiecznych pierwiastków śladowych, wykazała niską zawartość badanych pierwiastków (Rys. 4). Porównując zawartość pierwiastków śladowych w uzyskanym kompoście z dopuszczalnymi zawartościami określonymi w Rozporządzeniu Ministra Środowiska z dnia 6 lutego 2015 r. w sprawie komunalnych osadów ściekowych, można stwierdzić, że uzyskany produkt spełnia pod tym względem obowiązujące normy i może zostać wykorzystany na cele przyrodnicze z zastosowaniem do gleby. 


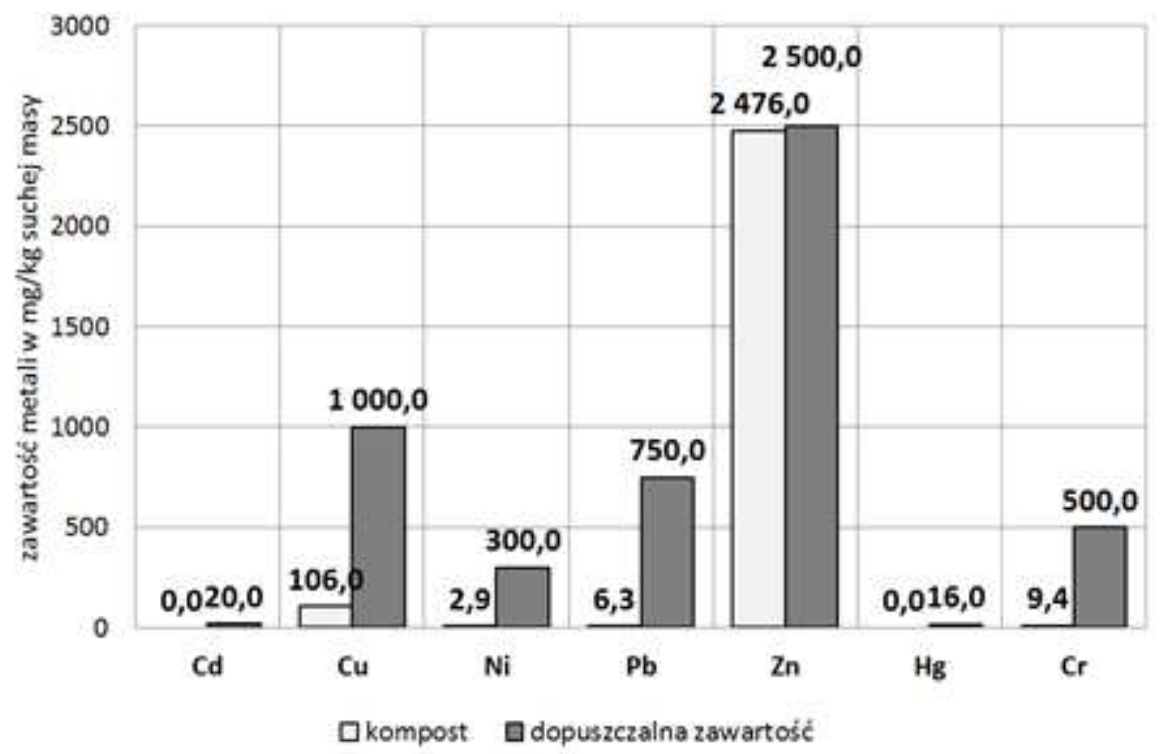

Rys. 4. Porównanie zawartości pierwiastków śladowych w uzyskanym kompoście z dopuszczalnymi zawartościami określonymi w Rozporządzeniem Ministra Środowiska z dnia 6 lutego 2015 r. w sprawie komunalnych osadów ściekowych

Fig. 4. Comparison of trace elements in the resulting compost with the limit values set out in the Regulation of the Minister of the Environment dated 6th February 2015. on municipal sewage sludge

Biorąc pod uwagę możliwość uzyskania statutu nawozu, środka nawozowego lub środka wspomagającego uprawę roślin należy określić przede wszystkim jeden z najbardziej limitujących czynników jak zawartość metali ciężkich. W przypadku linii Bionor Sludge, takim nawozem może być zarówno uzyskany kompost, a także popiół powstający po jego spaleniu. Dopuszczalna zawartość zanieczyszczeń w nawozach organicznych i organiczno-mineralnych oraz organicznych i organiczno-mineralnych środkach wspomagających uprawę roślin nie jest w uzyskanym materiale przekroczona i spełnia dopuszczalne normy dla obu finalnych rozwiązań (Rys 5).

Analizując kluczowe składniki nawozowe, jak azot (N), fosfor (P) i potas (K), uzyskany materiał (kompost lub popiól, w zależności od zastosowanych rozwiązań) można uznać, że spełnia podstawowe wymagania jakościowe dla nawozów organiczno-mineralnych w postaci stałej (Rys. 6). Osady ściekowe stosowane jako nawozy znacznie zwiększają zawartość próchnicy w glebie oraz są cennym źródłem składników pokarmowych roślin. Taki sposób zagospodarowania może stanowić nawożenie uzupełniające bądź zastępuje nawożenie nawozami naturalnymi $[8,9]$. Badania innych autorów także wskazują na możliwość zastosowania do produkcji nawozów popiołów ze spalania węgla brunatnego i wzbogacenia mieszanek siarczanem amonu, superfosfatem czy solami 


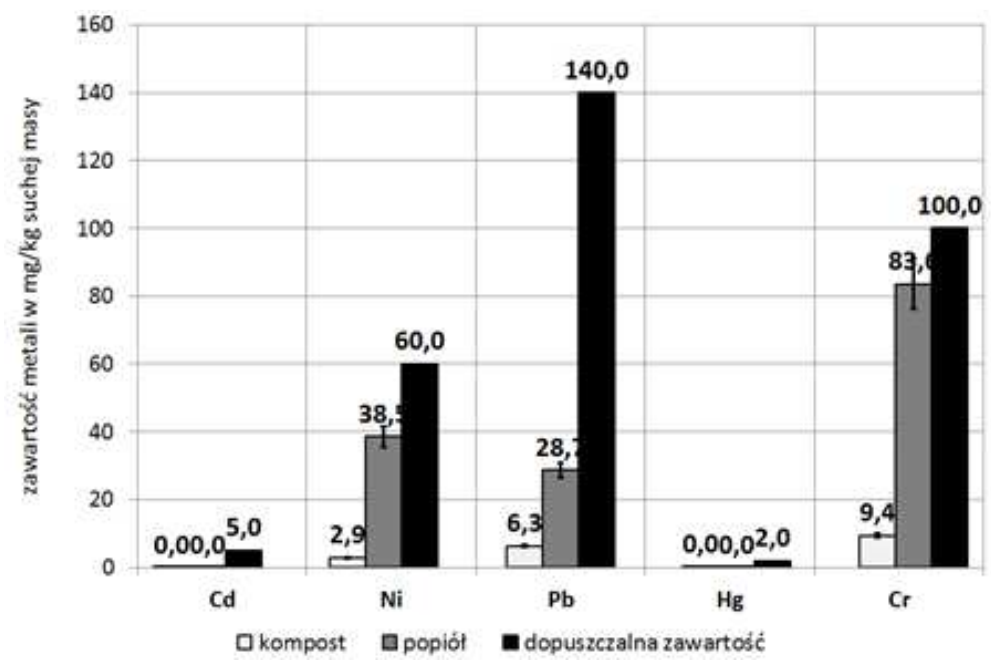

Rys. 5 Porównanie zawartości pierwiastków śladowych w uzyskanym kompoście z dopuszczalnymi zawartościami określonymi w Rozporządzeniu Ministra Rolnictwa i Rozwoju Wsi z dnia 18 czerwca 2008 roku w sprawie wykonania niektórych przepisów ustawy o nawozach i nawożeniu

Fig. 5. Comparison of the content of trace elements in the resulting compost with content limit specified in the Regulation of the Minister of Agriculture and Rural Development of 18th June 2008 on the implementation of certain provisions of the Act on fertilizers and fertilization

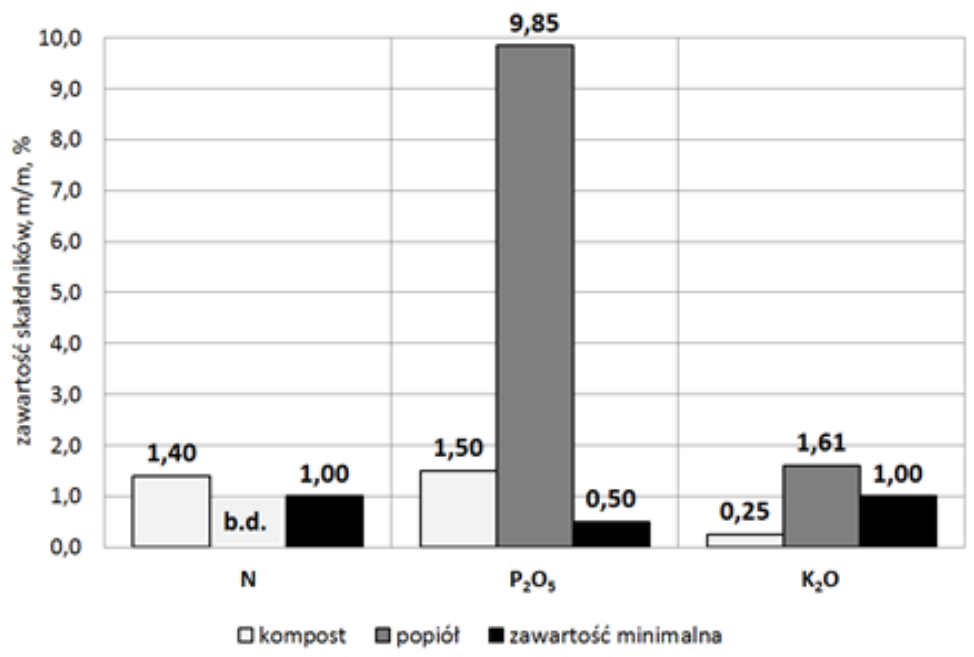

Rys. 6. Porównanie zawartości składników nawozowych w uzyskanym materiale z minimalnymi zawartościami określonymi w Rozporządzeniu Ministra Rolnictwa i Rozwoju Wsi z dnia 18 czerwca 2008 roku w sprawie wykonania niektórych przepisów ustawy o nawozach i nawożeniu

Fig. 6. Comparison of nutrient content in the resulting material with the minimum specified in the Regulation of the Minister of Agriculture and Rural Development of 18th June 2008 on the implementation of certain provisions of the act on fertilizers and fertilization 
potasowymi [10]. Inne rozwiązanie proponuje granulację osadów z dodatkiem związków potasu. Osady ściekowe spełniałyby tu nie tylko rolę źródła materii organicznej, ale także inhibitora wymywania z gleby frakcji mineralnych nawozu [11]. Wykorzystanie osadów ściekowych w procesach rekultywacji przyczynia się do możliwości odzysku cennych pierwiastków, na przykład azotu, fosforu i innych składników odżywczych, które są istotne dla wzrostu roślin [12].

Rozważając natomiast charakterystykę energetyczną uzyskanego kompostu (biomasy), przy cieple spalania rzędu $18,4 \mathrm{MJ}^{*} \mathrm{~kg}^{-1}$ i suchej masie rzędu $85 \%$ (Rys. 7), można badany materiał uznać za biomasę (zgodnie z ustawą o odnawialnych źródłach energii z dnia 20 lutego 2015), która podczas autotermicznego spalania wytwarza ciepło. W badaniach prowadzonych przez Zajonc uzyskano komposty o zawartości suchej masy $58 \%$, zawartości węgla $28 \%$, cieple spalania $11 \mathrm{MJ}^{*} \mathrm{~kg}^{-1}$ [13]. Podobne wartości ciepła spalania $11 \mathrm{MJ}^{*} \mathrm{~kg}^{-1}$ uzyskali inni autorzy [14]. W przeprowadzonych badaniach uzyskano natomiast komposty, których spalanie możliwe jest w procesie autotermicznym. Alternatywne przekształcanie odpadów komunalnych w biomasę jest cenne z uwagi na fakt włączenia przez UE odpadów komunalnych, ulęgających biodegradacji do definicji odnawialnych źródeł energii - dyrektywa 2001/77/WE [14]. W badaniach innych autorów [15] stwierdzono, że w zakresie procedur przetwarzania biomasy proces jej biosuszenia jest najbardziej efektywny dla energetycznego wykorzystania kompostu. W proponowanym układzie uzyskane ciepło może zostać także odpowiednio zagospodarowane, jako dodatkowe podgrzewanie kompostownika.

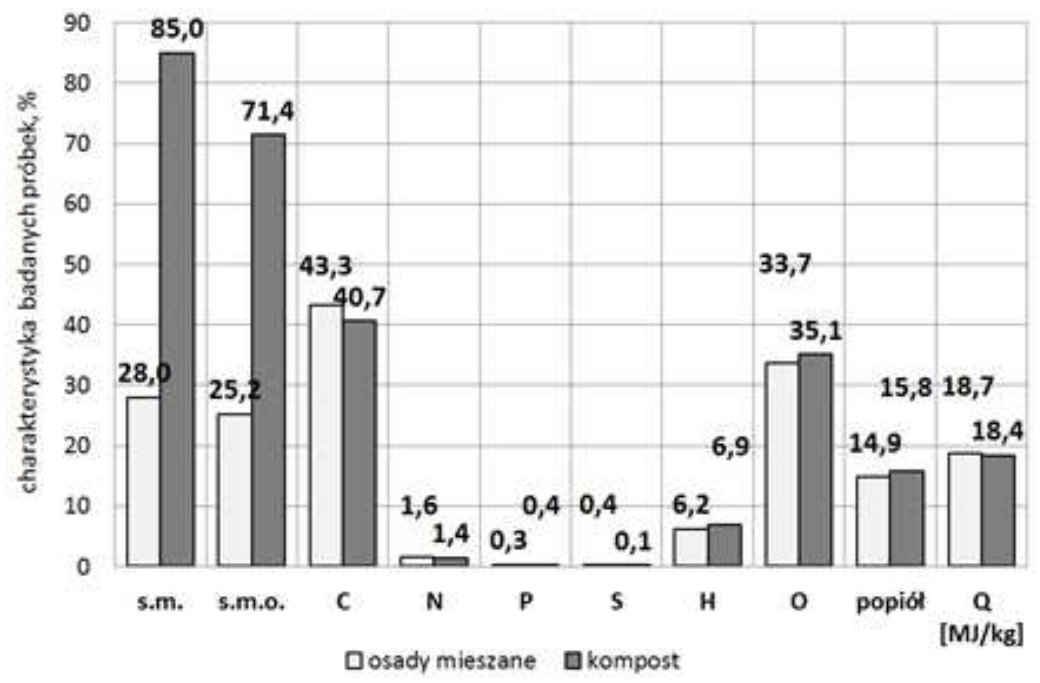

Rys. 7 Ogólna charakterystyka odwodnionych osadów mieszanych (wstępny oraz wtórny) i uzyskanego produktu termo - kompostowania

Fig. 7. General characteristics of dewatered sewage sludge (preliminary and secondary) and the resulting product of thermo - composting process 


\section{Wnioski}

Bionor Sludge to technologia, która polega na przekierowaniu, w możliwie największym stopniu, energii chemicznej zgromadzonej w ściekach komunalnych do osadów stanowiących rezerwuar substancji organicznej. Cały układ technologiczny oczyszczania ścieków i przeróbki osadów charakteryzuje się również wysoką efektywnością i elastycznością pracy przy modułowej zabudowie. Umożliwia to dostosowanie do układu technologicznego istniejących, modernizowanych oraz nowo - projektowanych oczyszczalni. Możliwe i w pełni zasadne jest zastosowanie wybranych elementów omawianej instalacji w ramach modernizacji istniejących obiektów.

Według rozporządzenia 341/2008 kompost nie może być stosowany w rolnictwie czy rekultywacji gleby jeśli nie spełnia norm zawartości substancji niebezpiecznych, ale może być użyty w celach energetycznych. W przypadku omawianego rozwiązania uzyskany kompost można zastosować do obu rozwiązań. Wytwarzanie kompostu $\mathrm{w}$ proponowanym układzie jest procesem nie emitującym substancje odorowe a sam kompost jest suchym i bezzapachowym substratem. Spalanie uzyskanej biomasy nie powoduje emisji niebezpiecznych pierwiastków, $\mathrm{z}$ uwagi na fakt braku takich $\mathrm{w}$ materiale wyjściowym. Natomiast uzyskany w trakcie procesu popiół stanowi cenny surowiec do produkcji nawozów fosforowych, potasowych i wapniowych. Najważniejszą korzyścią z zastosowania technologii jest brak osadów ściekowych, które miałyby trafić na składowisko.

Technologia Bionor Sludge jest aktualną odpowiedzią rynku na istniejące potrzeby i obowiązujące uwarunkowania prawne dla gminnych oczyszczalni ścieków o przepustowości do $1000 \mathrm{~m}^{3} * \mathrm{~d}^{-1}$. Dzięki swej innowacyjności i założeniom o możliwie najlepszym wykorzystaniu zasobów nawozowych i / lub energetycznych, umożliwia racjonalne funkcjonowanie oczyszczalni i tym samym znaczące odciążenie budżetu gmin i ostatecznie ich mieszkańców.

\section{Literatura}

[1] https://bdl.stat.gov.pl/BDL/dane/temat, Główny Urząd statystyczny, Bank Danych Lokalnych, Stan i Ochrona Środowiska, Komunalne oczyszczalnie ścieków, \{dostęp 19.11.2015r.\}.

[2] Rozporządzenie Ministra Środowiska z dnia 6 lutego 2015 r. w sprawie komunalnych osadów ściekowych.

[3] Rozporządzenie Ministra Rolnictwa i Rozwoju Wsi z dnia 18 czerwca 2008 roku w sprawie wykonania niektórych przepisów ustawy o nawozach i nawożeniu.

[4] Rozporządzenie Ministra Gospodarki z dnia 16 lipca 2015 r. w sprawie dopuszczania odpadów do składowania na składowiskach.

[5] Ustawa z dnia 20 lutego 2015 o odnawialnych źródłach energii.

[6] Bionor Sludge, materiały informacyjne firmy Bionor Sp. z o.o.

[7] Materiały przekazane przez firmę Bionor, analizy ścieków oczyszczonych.

[8] Rosik - Dulewska C.: Podstawy gospodarki odpadami. PWN, Warszawa 2008.

[9] Środa K., Kijo-Kleczkowska A., Otwinowski H.: Metody utylizacji osadów ściekowych. Archiwum Gospodarki Odpadami i Ochrony Środowiska, vol. 15, nr 2, 2013, s. 33-50. 
[10] Krzywy E., Wołoszczyk C., Możdżer E., Possibility of Producing Granulated Organic-Mineral Fertilizers from Some Municipal and Industrial Wastes, CHEMIK, vol. 69, no. 10,2015 , s. $684-697$.

[11] Wiater J., Łukowski A., Fitko H., Stelmach S., Sobolewski A., Figa J., Wstępne badania aplikacyjne granulowanych nawozów organiczno-mineralnych na bazie o sadów ściekowych. Zeszyty Naukowe Politechniki Białostockiej. Inżynieria Środowiska, Z. 16, t. 2, 2003, s. 233-237.

[12] Kacprzak M, Grobelak A, Grosser A, Prasad MNV.: Efficacay of Biosolids in Assisted Phytostabilization of Metalliferous Acidic Sandy SoilS with Five Grass Species. Int. J. Phytoremediation, vol. 16, no. 6, 2014, pp. 593-608.

[13] Zajonc O., Raclavská H., Juchelková D., Volfová M.: Energetic properties of compost, Journal of the Polish Mineral Engineering Society, no 2(28), 2011, pp. 77-78.

[14] Karcz H., Grabowicz M., Komorowski W.: Wykorzystanie biomasy pochodzącej z odpadów komunalnych do produkcji energii cieplnej i elektrycznej, Procesy Termiczne, Piece Przemysłowe i Kotły, nr 11-12, 2012, s. 8-18.

[15] Skanderová K, J. Malaták, J. Bradna. Energy use of compost pellets for small combustion plants, Agronomy Research, no. 13(2), 2015, pp.413-419.

Podziękowania: The research leading to these results has received funding from the Polish-Norwegian Research Programme operated by the National Centre for Research and Development under the Norwegian Financial Mechanism 2009-2014 in the frame of Project Contract No (POL NOR/201734/76)

\section{PHYSICAL AND CHEMICAL PROPERTIES OF BIOMASS AS ACHIEVED IN THE NEW SEWAGE SLUDGE PROCESSING TECHNOLOGY "BIONOR SLUDGE"}

\section{S u m m a r y}

The current legal situation in a certain way generates exploration and development of modern technologies that allow to solve the problem of sewage sludge management in Poland not only for large, but most of all for the small and medium-sized installation, because most of the produced sewage sludge in such installations currently is going to landfill. The aim of the study is to assess the functioning of the prototype line for processing of sewage sludge and the assessment of obtained biomass. Bionor Sludge Technology is a solution for municipal wastewater treatment plants with the capacity of up to $1000 \mathrm{~m} 3$ /day. The resulting sewage sludge is adequately treated in the installation and can be used in two ways: as compost or as a feedstock for the simple thermal installation, where it can be reused as the biomass in accordance with the law on renewable energy sources. The paper presents research allowing to a preliminary assessment of the quality of obtained product as potential fertilizer or energetic biomass. This technology involves redirection of the chemical energy stored in sewage sludge to constitute a reservoir of organic matter. The whole technological system allows to adjust to the technological system of existing, upgraded and newly designed waste water treatment plants. Bionor Sludge technology due to the innovation and assumptions about the best possible use of the resources of fertilizer and / or energy allows the rational functioning of the treatment plant, thus significantly reducing the load of the budget of municipalities and ultimately their inhabitants.

Keywords: sludge management, sewage treatment plants, compost, biomass, renewable energy

Przestano do redakcji: 29.01.2016 $r$.

Przyjęto do druku: 1.06.2016 r.

DOI: $10.7862 / \mathrm{rb} .2016 .106$ 